Савченко Олена В'ячеславівна доктор психологічних наук, професор, професор кафедри педагогіки та психології, ДВНЗ «Київський національний економічний університет імені Вадима Гетьмана», пр. Перемоги 54/1, м. Київ, 03057, тел.: (044) 371-61-05, https://orcid.org/000-0002-7069-7419

Михно Таісія Валентинівна здобувачка вищої освіти на першому (бакалаврському) рівні за спеціальністю «Психологія», ДВНЗ «Київський національний економічний університет імені Вадима Гетьмана», пр. Перемоги 54/1, м. Київ, 03057, тел.: (044) 371-61-05

\title{
КОНСТРУКТИВНІ ТА ДЕСТРУКТИВНІ ЗАСОБИ ПОДОЛАННЯ КРИЗ ПРОФЕСІЙНОГО СТАНОВЛЕННЯ СТУДЕНТІВ
}

Анотація. Мета нашого дослідження - визначити та здійснити опис перших трьох криз професійного становлення на етапі отримання вищої освіти. Професійне становлення розглядається як процес узгодження можливостей людини та вимог певної професійної діяльності через особистісні трансформації та розкриття потенціалу, засвоєння необхідних знань та вмінь. Криза професійного становлення - обов'язковий повторювальний етап процесу професійного становлення, у ході якого вирішується актуальне протиріччя через перебудову значеннєвих структур професійної свідомості, зміну засобів виконання діяльності. Було визначено 12 ознак криз: 1) відчуття несправедливості життя; 2) втрата безпеки; 3) відчай; 4) невпевненість в собі; 5) самотність; 6) страх; 7) зміна системи цінностей; 8) неадекватність реакцій; 9) підвищена тривожність; 10) дистанціювання в стосунках; 11) зміна відчуття часу; 12) фізичний спад. Охарактеризовано три кризи, які переживають студенти, навчаючись у закладах вищої освіти: «криза навчально-професійної орієнтації», «криза професійного навчання», «криза професійних експектацій». Визначені деструктивні засоби подолання криз: пасивність у виборі навчального закладу, перекладання відповідальності за вибір, уникнення «складної реальності», припинення професійного навчання, переорієнтація на забезпечення фінансової незалежності, зниження кар'єрних домагань та ін. Виокремлені конструктивні стратегій, а саме: звернення за допомогою до спеціаліста, розвиток рефлексивних здібностей, формування перспективи майбутнього, коригування вибору професій, поєднання роботи за спеціальністю 3 навчанням, поєднання навчання та наукових інтересів, ускладнення професійних задач та ін. Планується розробка методики психологічної діагностики переживання криз професійного становлення. 
Ключові слова: професійне становлення, ознака кризи, криза професійного становлення, засоби подолання, конструктивна стратегія подолання, деструктивна стратегія подолання.

Savchenko Olena Vyacheslavovna Doctor of Science (Psychology), Professor, Professor of the Department of Pedagogy and Psychology, Kyiv National Economics University named after Vadym Hetman, 54/1 Peremohy Ave., Kyiv, 03057, tel.: (067) 797-07-07, https://orcid.org/000-0002-7069-7419

Mykhno Taisiya Valentinovna Graduate of the first (bachelor's) level in Psychology, Kyiv National Economics University named after Vadym Hetman, 54/1 Peremohy Ave., Kyiv, 03057,tel .: (099 ) 433-01-89

\section{CONSTRUCTIVE AND DESTRUCTIVE STRATEGIES OF OVERCOMING CRISES OF STUDENTS` PROFESSIONAL FORMATION}

Abstract. The aim of our study is to identify and describe the first three crises of professional development at the stage of higher education. In article, the professional formation was considered as a process of reconciling human capabilities and requirements of a particular professional activity through personal transformations and potential forming, acquisition of necessary knowledge and skills. The crisis of professional development is a mandatory repetitive stage of the professional development process, during which the actual contradiction is resolved through the restructuring of the meaningful structures of professional consciousness, the change of performance means. 12 signs of crises were identified: 1) a sense of injustice in life; 2) loss of security; 3) despair; 4) self-doubt; 5) loneliness; 6) fear; 7) change the value system; 8) inadequacy of reactions; 9) increased anxiety; 10) distancing in relationships; 11) change of sense of time; 12) reduction in physical activity. Three crises that students have experienced while studying in higher education institutions have been described: "crisis of educational and professional orientation", "crisis of professional training", and "crisis of professional expectations". Destructive strategies of overcoming crises have been identified, namely: passivity in choosing an educational institution, shifting responsibility for the choice, avoiding "difficult reality", drop out of college, reorientation to ensure financial independence, reduction of career aspirations, etc. Constructive strategies have also been defined, namely: seeking help from a specialist, development of reflective abilities, formation of future prospects, adjustment of career choices, combining work in the specialty with study, combining training and research interests, complicating professional tasks, etc. It is planned to create the method of psychological diagnosis of experiencing a professional formation crisis.

Keywords: professional formation, sign of crisis, crisis of professional formation, means of overcoming, constructive strategy of overcoming, destructive strategy of overcoming. 
Постановка проблеми. Останнім часом все більше уваги суспільства акцентується на проблемі переривання студентами навчання у закладах освіти. Причин такого рішення існує багато. Студенти розчаровуються в своєму виборі, втрачають зацікавленість в майбутній професійній діяльності, змінюють свої пріоритети, обираючи заробітки, тощо. Узагальнюючи, можна сказати, що студенти переживають кризи професійного становлення протягом навчання.

Криза професійного становлення - це одна $з$ форм переживання кризового стану, яка $\epsilon$ важливим етапом в професіоналізації особистості, оскільки дозволяє розв'язати виникаючі суперечливості. 3 іншого боку - вона ускладнює діяльність людини, особливо, якщо у процесі подолання обираються деструктивні стратегії реагування.

За періодизацією Е. Зеєра [1], під час навчання, студенти стикаються 3 трьома кризами, які відбуваються в різні періоди їх перебування у вищому навчальному закладі. Будь-який кризовий стан знижує загальну успішність здобувачів освіти, негативно впливає на їх самопочуття та характер взаємодії 3 навколишнім середовищем. Частими ознаками кризи $є$ відсторонення від близьких людей, відчуття самотності та ворожості з-боку світу, втрата позитивних емоцій після виконаної роботи та ін. Молоді люди не тільки відчувають розчарування чи вагання щодо здійсненого вибору, а й не бачать сенсу у майбутній кар'єрі. Загалом, такі періоди навчання сприймаються як несприятливі для реалізації поставлених цілей, виконання навчальних завдань.

Незважаючи на значну актуальність даної теми, за останні десять років кількість наукових досліджень та публікацій суттєво скоротилась, хоча українські вищі за цей період впровадили новий компетентнісний підхід, змінили філософію освіти, отже дослідження ставлення студентів до освітнього процесу, періодизація кризовий етапів, вивчення засобів подолання криз - всі ці питання знов потребують дослідження.

Аналіз останніх досліджень і публікацій. На сучасному етапі дослідження проблеми професійного становлення особистості бракує універсальних моделей, оскільки більшість досліджень має вузькоспеціалізований характер, вивчаючи особливості професійного розвитку представників певної професії на певному етапі. Зосередимо уваг на тих працях, які ставили за мету виокремити загальні характеристики цього процесу. Зокрема, Г. Шихі та В. Козлов в своїх працях визначили загальні ознаки криз, які характеризують саме кризи професійного становлення [2], [3]. Л. Болікова та Ю. Шуригіна в своїй науковій праці описали ключові характеристики процесу професійного становлення особистості: адаптація до умов, що змінюються в процесі професійної діяльності, успішність у освоєнні професійно орієнтованих видів діяльності та ін. [4]. Е. Зеєром були описані кризи професійного становлення, конструктивні та деструктивні засоби подолання даних криз, а також запропонована загальна періодизація процесу професійного становлення. Відзначимо також, що Е. Зеєр визначив і чинники 
криз, а саме: наднормативну активність, соціоекономічні умови життя людини, вікові психофізіологічні зміни, рівень захопленості професійною діяльністю, зміни посади чи у життєдіяльності, якісну перебудову способів виконання професійних завдань [1]. Цікаво додати, що українська дослідниця М. Полухіна пов’язує перші кризи професійного становлення з домінуванням об'єктивних чинників (зміна провідної діяльності, соціальної ситуації), а більш пізні кризи 3 дією суб’єктивних чинників, таких як: «зміна «Я-концепції», перебудова професійної свідомості, зростання рівня домагань і самооцінки, прояв потреби в самоствердженні та самоздійсненні, тобто особистість сама стає ініціатором криз професійного розвитку» [5, С. 86]. Також, дослідниця розглядає кризу професійного становлення як інтегративний феномен, що поєднує когнітивний, емоційний, ціннісно-мотиваційний, поведінковий та особистісний компоненти. Інша українська дослідниця О. Питлюк-Смеречинська вважає, що суперечливості, які переживають студенти у процесі здобування освіти, обумовлені як внутрішньоособистісними чинниками (мотивації вибору професії, установки на навчання, рівня особистісної активності тощо), так і об’єктивними умовами навчально-професійної діяльності («дух вузу», «спрямованість групи», особливості форм і методів навчання, виробничої практики тощо). Серед засобів подолання цих суперечливостей автор визначає конструктивну рефлексію та формування адекватного образу «Я - як професіонал» [6].

Н. Чміль також розглядає дві основні групи детермінант процесу професійного становлення: особистісні чинники становлення у професії (професійна спрямованість, духовність, задоволеність навчальною діяльністю, організаторські здібності), i соціальні фактори (значущість соціального мікросередовища, міжособистісні стосунки у студентській групі, професійні якості викладачів, комунікативна компетентність особистості) [7]. Як результат процесу професіоналізації Б. Барчі виокремлює дві форми готовності суб'єкта до професійної діяльності: об'єктивна (наявність необхідних знань, вмінь, сформованих професійно-важливих якостей) та суб'єктивна (усталена мотивація до професійного розвитку) [8]. Також, звернемо увагу, що дослідниками вивчаються форми соціальної підтримки молодих фахівців, які допомагають швидше пройти кризові етапи, більш конструктивно подолати кризи професійного становлення. О. Федоров проаналізував основні форми супроводу, а саме: наставництво, стратегії внутрішньофірмової комунікації, конкурсного руху, залучення до професійних спільнот. Дослідник також підкреслює, що дуже важливо, щоб ці форми мали характер системний, неформальний, сталий, пролонгований, інакше їх вплив стає неефективним [9]. Як бачимо, багато дослідників розглядають кризи як важливі етапи процесу професійного становлення, одна недостатньо вивченими залишаються засоби проходження криз, долання протирічь.

Мета дослідження - охарактеризувати три перші кризи професійного становлення, які переживають здобувачі освіти та визначити конструктивні та деструктивні засоби їх подолання. 


\section{Задачі дослідження:}

1. Уточнити основні дефініції понять: «процес професійного становлення» та «криза професійного становлення».

2. Визначити основні ознаки кризи професійного становлення.

3. Охарактеризувати кризи професійного становлення, які переживають студенти навчальних закладів.

4. Відокремити конструктивні та деструктивні засоби подолання криз.

Виклад основного матеріалу. Процес засвоєння змісту професійної діяльності та адаптації до іiі умов в психології розглядається як процес професійного становлення особистості. Варто звернути увагу, що поняття «професійне становлення особистості» ми не можемо ототожнювати з поняттям «професійний розвиток» через суттєву різницю між ними: професійне становлення визначаємо через актуалізацію та реалізацію певних наявних ресурсів, які забезпечують опанування професією та виконання професійної діяльності, а професійний розвиток - це процес трансформації об'єкта при взаємодії з оточенням, який супроводжується здобуттям або втратами окремих професійних надбань [10]. Отже, поняття «професійний розвиток» - більш широке поняття, яке не відображає певної спрямованості. Поняття «професійне становлення» відображає ту форму професійного розвитку, яка забезпечує розкриття потенційний властивостей та реалізацію вже сформованих ресурсів.

Існує багато визначень поняття «процес професійного становлення». Так, на думку Б. Невзорова, професійне становлення - це «формування професійного самовизначення у конкретній професійній галузі залежно від ступеня узгодженості психологічних можливостей людини зі змістом та вимогами професійної діяльності, а також сформованості в особистості здатності адаптуватися до соціально-економічних умов, що змінюються, у зв'язку з влаштуванням своєї професійної кар'єри» [ 11, С. 65]. В. Симоненко визначає професійне становлення як «процес зміни особистості під впливом соціально-професійної ситуації, професійної діяльності та власної активності, спрямованої на самореалізацію у праці» [ 12, С. 47]. За Е. Зеєром, дане явище трактується як «процес розвитку та саморозвитку особистості, освоєння та самопроєктування професійно орієнтованих видів діяльності, визначення свого місця у світі професій, реалізації себе у професії та самоактуалізації свого потенціалу для досягнення вершин професіоналізму ...» [1, С. 27]. Проведений аналіз дефініцій, дозволяє розглядати професійне становлення як процес узгодження можливостей людини та вимог певної професійної діяльності через особистісні трансформації та розкриття потенціалу, засвоєння необхідних знань та вмінь, що сприяє ефективній самореалізації та адаптації до мінливих умов професійної діяльності.

Професійне становлення може бути розглянуто не лише в площині трансформації професійної діяльності, а також у площині змін особистості. Оскільки процес професійного становлення передбачає зміни особистості 
людини (формування професійно-важливих якостей, розвиток певних здібностей, корекція тих властивостей, які перешкоджають ефективній реалізації професійної діяльності), які мають прямий вплив на всі сфери діяльності, на стосунки з оточуючими та загальне бачення себе.

Процес професійного становлення можна представити як низку етапів, що поступово розгортаються. Перехід на новий етап передбачає кількісні та якісні трансформації. У праці Е. Зеєра були визначені наступні етапи процесу професійного становлення: 1) первинна амбівалентна оптація (до 15-ти років), 2) вторинна реалістична оптація (до 18-ти років), 3) професійна освіта та професійна підготовка (до $23-\mathrm{x}$ років), 4) професійна адаптація та первинна професіоналізація (до 27-ми років), 5) вторинна професіоналізація (до 33-х років), 6) професійна майстерність (до 60-ти років), 7) менторинг або наставництво (до 75-ти років) [1].

Перехід на новий етап професійного становлення може мати окремі ускладнення для людини в адаптації до змін чи нових ролей, це $\epsilon$ причиною появи криз, які є невід'ємною частиною професійного становлення. Загалом, криза - це «порушення внутрішньої рівноваги (психічної, душевної, емоційної) або гомеостазу людини, що виникає в результаті впливу середовища» [13, С. 3]. Кризи професійного становлення відбуваються у процесі засвоєння, адаптації та реалізації професійної діяльності. Е. Зеєр та Е. Симанюк під кризам професійного становлення розуміють «нетривалі за часом періоди (до року) кардинальної перебудови професійної свідомості, діяльності та поведінки особистості, зміни вектору їі професійного розвитку» [14, С. 194]. Професійні кризи часто протікають на тлі вікових криз, що ще більше ускладнює процес виходу з них, нормалізування діяльності. Саме ця складність в переживанні двох криз одночасно, вимагає знаходити ті способи подолання криз, які б стали не тільки найбільш ефективними, але й універсальними.

Загалом, кризи професійної становлення за класифікацією життєвих криз, яку запропонував П. Горностай, можна віднести до категорій «кризи становлення особистості» та «кризи самореалізації» [15]. Кризи становлення особистості охоплюють кризи, які виникають внаслідок зміни провідної діяльності особистості, появу нових ролей в житті людини. Саме тому ми можемо віднести кризу професійного становлення до даної категорії. До криз самореалізації П. Горностай відносить ті, що виникають через неможливість досягнення поставлених цілей 3 певних причин, якими можуть виступати: звільнення 3 роботи, виключення 3 університету, неочікувана зміна місця роботи чи вищого навчального закладу та інші.

На основі робіт В. Козлова [3] та Г. Шихі [2] нами було виокремлено 12 основних ознак кризи професійного становлення:

1. Відчуття несправедливості життя - переживання невдоволення від усвідомлення того факту, що твоя робота та ії результати оцінюються інакше, ніж праця та результати інших осіб; 
2. Втрата безпеки (ворожість оточуючих) - переживання ворожості навколишнього середовища, що супроводжується недовірою до інших, прагненням до безпеки та стабільності;

3. Відчай - переживання безнадійності через відсутність планів та перспектив на майбутнє, зневіра у своїй спроможності змінити ситуацію;

4. Невпевненість в собі - сумніви щодо результативності діяльності, низька оцінка власної компетентності;

5. Самотність - переживання нестачі близькості та спілкування 3 іншими людьми;

6. Страх - переживання загрози та дискомфорту нормальної життєдіяльності людини;

7. Зміна системи цінностей - зміни в поглядах на життя, значущості його важливих елементів;

8. Неадекватність реакцій - невідповідність реакцій зовнішнім подразникам та умовам ситуації;

9. Підвищена тривожність - переживання занепокоєння, внутрішнього напруження та зайвого збудження у ситуаціях з низьким рівнем загрози;

10. Дистанціювання в стосунках - відсторонення в стосунках з іншими;

11. Зміна відчуття часу - тенденція до недооцінки або переоцінки плинності часу;

12. Фізичний спад - переживання важкості виконання завдань та обов'язків через сильне відчуття втоми та виснаження, домінуюча потреба у відпочинку.

У нашому дослідженні основний інтерес був сфокусований на кризах професійного становлення, які переживають ще школярі та студенти, оскільки ми вважаємо, що саме конструктивне долання перших криз буде сприяти більш ефективному формуванню професійної ідентичності, адаптації до умов діяльності та засвоєнню змісту праці, а також легшому подоланню криз, які виникають на наступних етапах професійного становлення. Ми вважаємо, що кризи спрямовуються на вирішення виникаючих суперечливостей, які можуть бути вирішені деструктивними або конструктивними способи. У таблиці 1 ми систематизували засоби подолання криз. Основою для розробки стали праці Г. Шихі [2] та Е. Зеєра [1]. 


\section{Засоби подолання криз професійного становлення на етапі навчання в університеті}

\begin{tabular}{|c|c|c|c|}
\hline Криза & Опис & $\begin{array}{r}\text { Деструктивні } \\
\text { способи подолання }\end{array}$ & $\begin{array}{r}\text { Конструктивні } \\
\text { способи подолання }\end{array}$ \\
\hline $\begin{array}{l}\quad \text { Криза } \\
\text { навчально- } \\
\text { професійної } \\
\text { орієнтації } \\
\text { (завершення } \\
\text { середньої } \\
\text { освіти) }\end{array}$ & $\begin{array}{l}\text { - невдале } \\
\text { формування } \\
\text { професійних намірів } \\
\text { та їх реалізація [1]; } \\
\quad \text { - негативний } \\
\text { вплив випадкових } \\
\text { «доленосних» } \\
\text { моментів життя [1]; } \\
\quad \text { - суперечлива «я- } \\
\text { концепція», що } \\
\text { породжує конфлікти } \\
\text { між бажаннями та } \\
\text { реальними } \\
\text { можливостями; } \\
\text { - нереалістичні } \\
\text { уявлення щодо } \\
\text { професій; } \\
\text { - вплив на вибір } \\
\text { сподівань батьків/ }\end{array}$ & \begin{tabular}{l}
\multicolumn{1}{c}{ - небажання } \\
брати участь у \\
пошуку та виборі, \\
перекладання \\
відповідальності за \\
вибір навчального \\
закладу на іншого; \\
$\quad$ - ігнорування \\
певної інформації, \\
яка ускладнює \\
вибір; \\
$\quad$ - уникнення \\
«складної \\
реальності» вибору \\
за допомогою \\
різних форм \\
залежності.
\end{tabular} & $\begin{array}{l}\quad \text { - звернення за } \\
\text { допомогою до } \\
\text { спеціаліста для } \\
\text { професійного та } \\
\text { особистісного } \\
\text { самовизначенні [1]; } \\
\quad \text { - поступова, } \\
\text { завчасна орієнтація у } \\
\text { професіях та своїх } \\
\text { пріоритетах; } \\
\quad \text { - розвиток } \\
\text { рефлексивних } \\
\text { здібностей, які є } \\
\text { підставою для } \\
\text { самоаналізу; } \\
\quad \text { - формування } \\
\text { перспективи } \\
\text { майбутнього (на 5-10 } \\
\text { років). }\end{array}$ \\
\hline \begin{tabular}{l}
\multicolumn{1}{c}{ Криза } \\
професійного \\
навчання \\
(навчання в \\
закладі \\
освіти)
\end{tabular} & $\begin{array}{l}\text { - зміна } \\
\text { соціально- } \\
\text { економічних умов } \\
\text { життя [1]; } \\
\quad \text { - перебудова } \\
\text { провідної діяльності } \\
\text { [1]; } \\
\text { - конфлікт між } \\
\text { бажанням комфорту й } \\
\text { безпеки та } \\
\text { збереженням } \\
\text { індивідуальності [2]; } \\
\text { - невдоволення } \\
\text { обраним навчальним } \\
\text { закладом [1]. }\end{array}$ & $\begin{array}{l}\text { - припинення } \\
\text { професійного } \\
\text { навчання; } \\
\quad \text { - ригідне } \\
\text { дотримання } \\
\text { сформованих } \\
\text { упереджень щодо } \\
\text { професії, } \\
\text { ігнорування фактів; } \\
\text { - переорієнтація } \\
\text { на забезпечення } \\
\text { фінансової } \\
\text { незалежності. }\end{array}$ & $\begin{array}{l}\text { - зміна мотивів } \\
\text { навчальної діяльності } \\
{[1] ;} \\
\text { - коригування } \\
\text { вибору професї, } \\
\text { спеціальності, } \\
\text { факультету [1]; } \\
\text { - поєднання } \\
\text { роботи за } \\
\text { спеціальністю з } \\
\text { навчанням; } \\
\text { - поєднання } \\
\text { навчання та наукових } \\
\text { інтересів (самостійне } \\
\text { обирання теми } \\
\text { дослідження); } \\
\text { - практикування } \\
\text { та експериментування } \\
\text { у сфері проф. } \\
\text { діяльності. }\end{array}$ \\
\hline
\end{tabular}




\section{Криза}

професійних

експектацій -

(адаптація до

соціально-

професійної

ситуаціі)

$$
\text { -проблеми }
$$

професійної адаптації

(взаємовідносини 3

різновіковими

колегами) [1];

-освоєння нової

провідної професійної

діяльності [1];

-конфлікт між

двома основними

імпульсами:

a) створити

комфорт і безпеку за

готовим зразком;

б) прагнення

експериментувати [2].
- звільнення,

зміна спеціальності

та професії [1];

- зниження

кар'єрних домагань,

орієнтація на

стабільне місце

роботи без

перспективи росту;

- втрата

ініціативності,

відмова від

прийняття

відповідальних

рішень;

- ранні прояви

емоційного

вигорання
- активізація

професійних зусиль

[1];

- коригування

мотивів праці та

"я-концепції" [1];

- поєднання

професійної

діяльності 3

подальшим

навчанням на інших

освітніх рівнях;

- підвищення

кваліфікації;

- розширення та

ускладнення

професійних задач.

Першою кризою професійного становлення можна назвати кризу навчально-професійної орієнтації, яка може протікати паралельно 3 підлітковою кризою у віці від п’ятнадцяти до вісімнадцяти років. В даний період учень починає замислюватись щодо свого подальшого навчання та має робити вибір: продовжувати навчання у закладах середньої освіти або ж вступати в коледж/технікум для отримання профільних знань. У цей період підліток переживає багато негативних емоцій щодо свого майбутнього, відчуває потребу або тиск 3 боку оточуючих 3 приводу професійного визначення, обрання напряму професійної діяльності. Несприятливим фактором, що ускладнює вибір та посилює вагання, $\epsilon$ несформована «Я-концепції» або нереалістичні уявлення про себе. Е. Зеєр, описуючи цей етап, зосереджував увагу на такому несприятливому чиннику як протиріччя між бажанням просто «красиво прожити» та очікуваннями зі сторони соціуму, тиском совісті (ідеальних уявлень про позитивні та негативні форми поведінки) [1]. Вагомий вплив на ситуацію вибору професії спостерігається 3 боку батьківських очікувань, які можуть вербально чи невербально транслюватись дитині. Незріла ідентичність та суперечлива «Я-концепція» часто проявляються у достатньо песимістичних уявленнях про власне майбутнє. Важливо враховувати уразливість підлітка через його високу схильність до будь-яких зовнішніх впливів, що в майбутньому може відбитися на процесі формування нереалістичних або неадекватних професійних намірів, реалізація яких призведе до переживання невдачі. 
Можливі деструктивні та конструктивні шляхи подолання цієї кризи. Багато підлітків намагаються відкласти чи відтягнути прийняття рішення щодо вищого навчального закладу, бо дане питання сприймається як занадто складне чи болюче, особливо у випадку тиску 3-боку батьків. Згодом, це питання починає ставати більш гострим, і тиск може посилюватись, тому підліток може перекласти відповідальність за вибір навчального закладу на близьких осіб, або у процесі вибору просто не приймати активної участі, займаючи позицію слухача. Інший варіант - це занадто поспішний та необдуманий вибір через брак часу та інформації, який надалі може мати негативні наслідки. Часто підліток починає сприймати життя як занадто «складну реальність», помічаючи лише збільшення відповідальності та складнощів, оскільки необхідно приймати доленосні рішення. Зменшенню відповідальності сприяє уникання таких утруднень, відхід від реальності шляхом формування певних залежностей від інтернету, соціальних мереж, ігор та ін. Конструктивні способи подолання передбачають ефективну взаємодію дорослих з підлітком, отримання допомоги у виборі навчального накладу, професійній орієнтації. Іноді ситуація вибору потребує допомоги не лише батьків та вчителів, а й психолога-спеціаліста у професійному та особистому самовизначенні. Конструктивною вважаємо також стратегію завчасної орієнтації у професіях та своїх вподобаннях, що знижує ймовірність прийняття рішення при нестачі часу (додаткового чинника переживання кризи). Орієнтації у пріоритетах, бажаннях та власних очікуваннях допомагає розвиток рефлексивних вмінь та навичок. Високий рівень рефлексії забезпечує краще розуміння своєї поведінки, вчинків та реакцій, що сприяє більш усвідомленому та раціональному вибору особистості, який враховує і індивідуальні особливості, i інтереси, i схильності. Також забезпечує швидке проходження кризового періоду формування реалістичних перспектив на майбутнє, які сприятимуть і вибудовуванню «Я-Майбутнього» як важливої складової «Я-концепції».

Друга криза відбувається безпосередньо у процесі навчання у вищому навчальному закладі та може охоплювати період від вісімнадцяти до двадцяти двох років. Вона дотична до вікової кризи, яка має умовну назву «криза виривання коренів». Молода людина у період навчання вирішує питання сепарації від батьків, інколи, намагаючись пришвидшити цей процес. Студенти відчувають набагато більше «свободи» в своїй життєдіяльності, порівняно 3 минулими періодами, а тому часто намагаються поєднувати навчання та роботу, що може суттєво завадити отримуванню якісного рівня освіти. В певних ситуаціях студент взагалі відкидає навчання на другий план та повністю займається забезпеченням фінансової незалежності від батьків. Ця ситуація також підкріплюється тим, що зазвичай у студента набагато більше грошей, ніж у старшокласника, і це посилює відчуття свободи. Отже формується установка на «швидкий заробіток» за допомогою низько кваліфікованої роботи. Останнє також не сприяє навчанню, є частою причиною уходу з університетів. Однак, 
навіть при відсутності потреби у заробітках очікування від навчання часто не узгоджуються з реальністю, що може призводити до різних реакцій: адаптація до існуючих умов, заперечення невідповідності, посилення романтичних уявлень та ін. Молода людина може потрапити в конфлікт, де одна їі частина намагається стати індивідуальністю та «не втрачати себе» (тобто прагне продовжувати освіту), а інша - забезпечити свій комфорт (відпочивати, не напружуватись, задовольняти свої бажання й потреби та ін.).

Деструктивні способи подолання включають в себе припинення професійного навчання без подальшого відновлення, загальне знецінення корисності освіти. Як раніше було зазначено, студент може переорієнтуватись на матеріальне забезпечення своїх потреб за допомогою роботи не за спеціальністю. Втрачається час, найбільш сприятливий для формування та засвоєння професійних вмінь та навичок. В іншому випадку, студент, не маючи зацікавленості у навчальній діяльності, орієнтується лише на отримання червоного диплому чи найвищих балів, що супроводжуються механічним заучуванням матеріалу без усвідомлення його, без включення інформації в загальну систему. У певної частини здобувачів освіти спостерігаються ригідні упередження щодо обраної професійної діяльності, вони продовжують романтизувати професію, ігноруючи факти реальності, що заважає адекватній адаптації їх до вимог навчання (вони не помічають складнощів, а отже не готують себе до реальної практичної діяльності, вважають, що «все само собою вирішиться»). Нами визначені і конструктивні способи подолання кризи. Одним 3 таких способів є поєднання роботи за спеціальністю 3 навчальною діяльністю, що суттєво збільшує можливість перевірити свою професійну придатність. Така стратегія має декілька форм: стажування, практикування під супервізію досвідченого фахівця, праця помічником спеціаліста та ін. Інша стратегія - розширювати сферу своїх професійних інтересів за допомогою проходження додаткових курсів (онлайн або офлайн), отримання освіти за додатковою спеціальністю, проходження тренінгів розвитку соціальних навичок. Окремої уваги заслуговує зміна мотивів навчальної діяльності (переорієнтації на практичне застосування знань, знаходження «ідеї, цікавої проблеми, мети», яка допомагає засвоєнню великого обсягу інформації) [1]. Певні студенти, як зазначав Е. Зеєр, починають критично ставитись до отриманої інформації, усвідомлено підходять до вибору навчальних дисциплін та форм активності при вивченні їх. Особливу увагу вони починають приділяти саме тим навчальним курсам, які відповідають їх меті стати професіоналом, менше зусиль докладають на вивчення тих дисциплін, які не задовольняють іiі, не викликають в них інтересу. При відсутності такої цілі, молода людина часто бездумно вивчає матеріал, який потім не може використати у діяльності. Ще одним варіантом вирішення кризи, який виокремив Е. Зеєр, є вдалий вибір наукового керівника та цікавої теми для наукового дослідження, оскільки конструктивна співпраця 3 фахівцем може суттєво посилити інтерес до 
майбутньої діяльності. Останній спосіб, який варто зазначити, це - коригування вибору професії чи навчального закладу, що є більш ефективним після перших двох років навчання, коли студент вже зорієнтувався, усвідомив свої пріоритети.

Остання криза, яку ми представили у таблиці 1, є криза професійних експектацій, яка проходить паралельно з віковою кризою «пошуки в двадцять років» та умовно триває від двадцяти трьох до двадцяти семи років. Дана криза може відбуватись на останніх курсах навчання у закладах вищої освіти, коли студенти намагаються працевлаштуватись за спеціальністю. Досвід роботи на першому робочому місці є вкрай важливим, оскільки саме на етапі адаптації відбуваються остаточні узгодження очікувань від професійної діяльності та реальних умов праці. Певні особи, попри усвідомлення невідповідності очікувань і реальності, намагаються залишитись у професій, підлаштовуватись під вимоги, не переживаючи при цьому ні інтересу, ні задоволення. Така пасивна позиція $€$ частою причиною раннього вигорання, формування депресивного патерну поведінки, переживання низької самоефективності. У цей період часто спостерігається конфлікт між прагненням до безпеки, стабільності та експериментуванням. Прагнення до комфорту та безпеки спрямовує молодого спеціаліста на використання готових зразків або алгоритмів. Людина у такому випадку відчуває себе дещо «обмеженою», такою, що не має «свободи» в поведінці. Прагнення до нового, до експериментування часто супроводжується ризиком, який може посилити невпевненість та розгубленість. Етап адаптації до умов професійної діяльності часто затягується, оскільки у молодого спеціаліста не формується відчуття власної компетентності та впевненості в успішності дій. Як наслідок, людина може часто змінювати місце роботи. Ускладнення у процес адаптації привносить і пристосування до нового колективу, особливо різновікового за складом.

Деструктивні способи подолання даної кризи включають в себе звільнення 3 роботи, зміну спеціальності та професії загалом, або перехід на навчання на іншу спеціальність без спроби реалізації в раніше обраній спеціальності. Як правило це відбувається після першого негативного досвіду. Іншим деструктивним варіантом є постійна зміна місця роботи як реакція на складну ситуацію, невдачу чи конфлікт. Спостерігається також зниження кар'єрних домагань: молода людина починає орієнтуватись на стабільність, обираючи таке місце роботи, яке не передбачає можливості подальшого особистісного та професійного зростання. Наявними $є$ також ранні прояви емоційного вигорання, які В. Бойко відніс до фази «напруження», а саме: незадоволеність собою, відчуття «загнаності в клітку», тривога та депресія. В окремих випадках можуть спостерігатися і прояви фази «резистенції»: неадекватне вибіркове емоційне реагування, редукція професійних обов'язків [16]. Конструктивні способи подолання кризи полягають в активації «професійних зусиль», які спрямовуються на поступове перевищення своїх можливостей, «підняття 
верхньої планки» (рівня домагань). Наступний спосіб - це коригування мотивів професійної діяльності: знаходження, уточнення сенсу своєї роботи. Це сприяє підвищенню рівня компетентності та самоефективності, що, у свою чергу, збільшує зацікавленість у роботі. Дуже ефективним способом $\epsilon$ пошук наставника, який в перші місяці роботи допоможе адаптуватись до нового середовища та стати членом колективу. Достатня кількість організацій практикує такий спосіб підбору наставника до кожного «новачка». Ефективною також є стратегія поступового підвищення складності задач, що сприяє більш легкій адаптації до умов праці. Послідовність та достатність часу - важливі фактори поступової адаптації, які усувають зайву напругу та тривогу. Останнім варіантом, представленим у таблиці, є поєднання професійної діяльності 3 подальшим навчанням на інших освітніх рівнях, або проходження курсів підвищення кваліфікації, отримання суміжної спеціальності.

Висновки. Нами було проаналізовано зміст понять «професійне становлення» та «криза професійного становлення». Процес професійного становлення визначається нами як узгодження можливостей людини та вимог певної професійної діяльності через особистісні трансформації та розкриття потенціалу, засвоєння необхідних знань та вмінь, що сприяє ефективній самореалізації та адаптації до мінливих умов професійної діяльності. Кризу професійного становлення ми розглядаємо як обов'язковий повторювальний етап процесу професійного становлення, у ході якого вирішується актуальне протиріччя через перебудову значеннєвих структур професійної свідомості, зміну засобів виконання діяльності, уточнення «вектора професійного розвитку». Кризи професійного становлення мають специфічні ознаки, за якими цей етап можна діагностувати, а саме:1) відчуття несправедливості життя; 2) втрата безпеки (ворожість оточуючих); 3) відчай; 4) невпевненість в собі; 5) самотність; 6) страх; 7) зміна системи цінностей; 8) неадекватність реакцій; 9) підвищена тривожність; 10) дистанціювання в стосунках; 11) зміна відчуття часу; 12) фізичний спад. Визначені конструктивні та деструктивні засоби подолання криз («кризи навчально-професійної орієнтації», «кризи професійного навчання», «кризи професійних експектацій», які відбуваються під час навчання студентів у навчальних закладах. У перспективі планується розробка методики діагностики кризових переживань, яка буде враховувати визначені ознаки криз професійного становлення. Це надасть можливість перевірити припущення щодо кількості криз, їх специфіки переживання у процесі професійного становлення.

\section{Лimepamypa:}

1. Зеер Э. Ф. Психология профессий: Учебн.пособие. Москва: Академический Проект, Фонд «Мир», 2005. 336 с.

2. Шихи Г. Возрастные кризисы. СПб.: Ювента, 1999. 436 с.

3. Козлов В.В. Личностный кризис - структурные и гендерные особенности. Ярославль: ЯрГУ, 2004. URL: http://zi-kozlov.ru/articles/1120-personalitycrisis. 
4. Боликова Л.Ю., Шурыгина Ю.А. Сущность понятия «профессиональное становление личности» в современном знании // Известия ПГПУ им. В. Г. Белинского. 2011. № 24. С. 573-575.

5. Полухіна М.П. Особливості поведінкового компонента кризи професійного становлення особистості у ранній дорослості // Psychological journal. 2018. № 2 (12). С. 83-98. DOI: https://doi.org/10.31108/2018vol12iss2pp83-98.

6. Питлюк-Смеречинська О.Д. Психологічні особливості професійного становлення майбутніх фахівців в інтегрованому освітньому середовищі // Актуальні проблеми навчання та виховання людей з особливими потребами: зб. наукових праць. Київ: Унів-т «Україна», 2013. № 10 (12). С. 223-238.

7. Чміль Н.С. Концептуальна модель процесу професійної соціалізації майбутніх священослужбовців // Вісник ХНПУ імені Г.С. Сковороди. Психологія. 2016. Вип. 52. С. $235-$ 244. DOI: dx.doi.org/10.5281/zenodo.44920

8. Барчі Б. Psychological features of the future specialist`s professional formation // Вісник Національного університету оборони України. $2021 . \quad$ № 5 (63). С. $5-11$. DOI: https://doi.org/10.33099/2617-6858-2021-63-5-5-11

9. Федоров О.Д. Стратегии сопровождения молодого учителя в процессе профессионального становления: результаты эмпирического исследования // Проблемы современного педагогического образования. 2021. № 72-1. С. 279-283.

10. Дружилов С.А. Индивидуальный ресурс человека как основа становления профессионализма: монография. Воронеж: Научная книга, 2010. 262 с.

11. Невзоров Б.П. Профессиональное становление учителя в системе многоуровневого университетского образования в регионе: диссерт. д. пед. наук, 13.00.01: Общая педагогика, история педагогики. Москва, 1998. 400 с.

12. Общая и профессиональная педагогика / Под ред. Симоненко В.Д. Москва: Вентана-Граф, 2006. 368 с.

13.Мягких Н.И., Ларина Н.И. Теория и практика психологии кризисных ситуаций // Психология и право. 2011. Том. 1, № 2. URL: https://psyjournals.ru/psyandlaw/ 2011/n2/40903.shtml.

14. Зеер Э.Ф., Сыманюк Э.Э. Эмоциональный компонент в профессиональном становлении педагога // Мир психологии. 2002, № 4 (32), С. 194 - 203. URL: https://pedlib.ru/Books/4/0097/4_0097-1.shtml.

15. Горностай П.П. Личность и роль. Ролевой подход в социальной психологии личности. Киев: Интерпресс ЛТД, 2007. 312 с.

16. Бойко В.В. Энергия эмоций в общении: взгляд на себя и на других. Москва: Информационно-издательский дом "Филинъ", 1996. 472 с.

\section{References:}

1. Zeer E. F. (2005) Psykholohiya profesiy: Uchebn. Posobie [Psychology of professions: Textbook]. Moskva: Akademichnyy Proekt, Fond «Svit». 336 s. [in Russian].

2. Shihi G. (1999) Vozrastnyie krizisyi [Age crises]. Sankt-Peterburg: Yuventa. 436 s. [in Russian].

3. Kozlov V.V. (2004) Lichnostnyiy krizis - strukturnyie i gendernyie osobennosti [Identity crisis - structural and gender features]. Yaroslavl: YarGU. URL: http://zi-kozlov.ru/articles/1120personalitycrisis [in Russian].

4. Bolikova L.Yu., Shuryigina Yu.A. (2011) Suschnost ponyatiya «professionalnoe stanovlenie lichnosti» $\mathrm{v}$ sovremennom znanii [The essence of the concept of "professional development of personality" in modern knowledge]. Izvestiya PGPU im. V. G. Belinskogo Proceedings of PSPU named after V. G. Belinsky, 24, 573-575 [in Russian].

5. Polukhina M.P. (2018) Osoblyvosti povedinkovoho komponenta kryzy profesiinoho stanovlennia osobystosti u rannii doroslosti [Features of the behavioral component of the crisis of 
professional development of personality in early adulthood]. Psychological journal, 2 (12), 83-98. DOI: https://doi.org/10.31108/2018vol12iss2pp83-98. [in Ukrainian].

6. Pytliuk-Smerechynska O.D. (2013) Psykholohichni osoblyvosti profesiinoho stanovlennia maibutnikh fakhivtsiv $\mathrm{v}$ intehrovanomu osvitnomu seredovyshchi [Psychological features of professional development of future specialists in an integrated educational environment]. Aktualni problemy navchannia ta vykhovannia liudei $z$ osoblyvymy potrebamy: $z b$. naukovykh prats Current issues of education and upbringing of people with special needs: a coll. of scientific papers. Kyiv: Univ-t «Ukraina», 10 (12), 223-238 [in Ukrainian].

7. Chmil N.S. (2016) Kontseptualna model protsesu pofesiinoi sotsializatsii maibutnikh sviashchenosluzhbovtsiv [Conceptual model of the process of professional socialization of future clergy]. Visnyk KhNPU imeni H.S. Skovorody. Psykholohiia - Bulletin of KhNPU named after G.S. Skovoroda. Psychology, 52, 235-244. DOI: dx.doi.org/10.5281/zenodo.44920 [in Ukrainian].

8. Barchi B. (2021) Psychological features of the future specialist's professional formation. Visnyk Natsionalnoho universytetu oborony Ukrainy - Bulletin of the National University of Defense of Ukraine, 5 (63), 5-11. DOI: https://doi.org/10.33099/2617-6858-2021-63-5-5-11 [in English].

9. Fedorov O.D. (2021) Strategii soprovozhdeniya molodogo uchitelya v protsesse professionalnogo stanovleniya: rezultatyi empiricheskogo issledovaniya [Strategies of a young teacher`s maintenance in the process of professional development: results of an empirical study]. Problemyi sovremennogo pedagogicheskogo obrazovaniya - Problems of modern teacher education, 72-1, 279-283 [in Russian].

10. Druzhilov S.A. (2010) Individualnyiy resurs cheloveka kak osnova stanovleniya professionalizma: monografiya [Individual human resource as the basis for the formation of professionalism: monograph.]. Voronezh: Nauchnaya kniga. 262 s. [in Russian].

11.Nevzorov B.P. (1998) Professionalnoe stanovlenie uchitelya $\mathrm{v}$ sisteme mnogourovnevogo universitetskogo obrazovaniya $\mathrm{v}$ regione [Professional development of a teacher in the system of multilevel university education in the region]: dissert. doc. ped. nauk, 13.00.01: Obschaya pedagogika, istoriya pedagogiki - General pedagogy, history of pedagogy. Moskva. 400 s. [in Russian].

12. Obschaya i professionalnaya pedagogika [General and professional pedagogy] / Pod red. Simonenko V.D. Moskva: Ventana-Graf, 2006. 368 s. [in Russian].

13. Myagkih N.I., Larina N.I. (2011) Teoriya i praktika psihologii krizisnyih situatsiy [Theory and practice of psychology of crisis situations]. Psihologiya i parvo - Psychology and Law, T.1, 2. URL: https://psyjournals.ru/psyandlaw/2011/n2/40903.shtml [in Russian].

14.Zeer E.F., Syimanyuk E.E. (2002) Emotsionalnyiy komponent v professionalnom stanovlenii pedagoga [Emotional component in the professional development of a teacher]. Mir psihologii - The world of psychology, 4 (32), 194-203. URL: https://pedlib.ru/Books/4/0097/4_0097-1.shtml. [in Russian].

15.Gornostay P.P. (2007) Lichnost i rol. Rolevoy podhod v sotsialnoy psihologii lichnosti [Personality and role. Role approach in the social psychology of personality]. Kiev: Interpress LTD, $312 \mathrm{~s}$. [in Russian].

16. Boyko V.V. (1996) Energiya emotsiy v obschenii: vzglyad na sebya i na drugih [The energy of emotions in communication: a look at yourself and others]. Moskva: Informatsionnoizdatelskiy dom "Filin'", 472 s. [in Russian]. 